УДК 351:323.1(477)

\title{
Перспективи застосування теорії інтегруючого мультикультуралізму при виробленні концептуальних піАхоАів Ао управління етнокультурною різноманітністю в Україні
}

\author{
^.Я. KOPHAT \\ Аьвівський регіональний інститут Аержавного управління Національної \\ акалемії державного управління при Презилентові України, \\ м. Аьвів-Брюховичі, Україна, E-mail: lesya_kornat@ukr.net
}

\begin{abstract}
Авторське резюме
У статті обгрунтовано складові публічного управління етнокультурною різноманітністю в Україні на основі концептуальної моделі ліберального інтегруючого мультикультуралізму. Доведено, що нехтування проблемами етнонаціонального розвитку містить небезпеку перетворити фактор етнокультурної різноманітності з культурного надбання на джерело конфліктів та протиріч, призвести до втрати територіальної цілісності країни. Визначено основні проблеми, які є наслідком непослідовної етнонаціональної політики в Україні. На основі авторського визначення термінів «управління етнокультурною різноманітністю», «модель» та «концептуальна модель» управління етнокультурною різноманітністю визначено основні принципи публічного управління етнокультурною різноманітністю та запропоновано як найбільш прийнятну для умов України концептуальну модель управління етнокультурною різноманітністю - інтегруючий мультикультуралізм, метою якого є інтеграція та консолідація. Визначено елементи даної концептуальної моделі та доведено, що їі перевага, порівняно з іншими моделями управління етнокультурною різноманітністю, полягає у сприянні процесам суспільної інтеграції шляхом підтримки культурної різноманітності, захисту індивідуальних та колективних прав етнокультурних груп

(C) Л.Я. Корнат, 2015
\end{abstract}


- без порушення конституційних прав особи у суспільстві в цілому, створення умов для збереження самобутності етнокультурних груп, а також розвитку загальнонаціональної соцієтальної культури, котра дозволить забезпечити формування спільної для всіх громадян національної ідентичності.

Ключові слова: управління етнокультурною різноманітністю, ліберальний інтегруючий мультикультуралізм, теоретична модель публічного управління етнокультурною різноманітністю, принципи публічного управління етнокультурною різноманітністю.

\title{
Perspectives of integrating multiculturalism theory appliance in development of the conceptual approaches to the management of ethnocultural diversity in Ukraine
}

\author{
L.JA. KORNAT \\ Lviv regional institute of public administration, the National Academy \\ of public administration, office of the President of Ukraine, L'viv-Bryuxovy chi, \\ Ukraine, E-mail: lesya_kornat@ukr.net
}

\begin{abstract}
It is proved in the article that the components of public administration of ethnocultural diversity in Ukraine are based on a concept model for integrating liberal multiculturalism. It is proved that if the problems of ethnic development are being neglected, it could expose the danger to convert the factor of ethnic and cultural diversity from cultural heritage into the core of conflicts and controversies, cause loss of the territorial integrity. Hereafter the main problems resulting from inconsistent ethnic policy in Ukraine are defined. Based on the author's terms definitions of 'management of ethnocultural diversity', 'model' and 'conceptual model' for managing ethnocultural diversity, it has been determined the basic principles of public administration for ethnocultural diversity and proposed a conceptual (theoretical) model for management of ethnocultural diversity in Ukraine. Certain elements of the conceptual model of ethnocultural diversity management are designated with the aim for integration and consolidation. It is proved that the advantage of the management model for ethnocultural diversity, which is based on multiculturalism, is to facilitate the process of social integration, support for cultural diversity, protect individual rights of the representatives of the ethnic and cultural groups, make conditions for preserving the identity of ethnic and cultural groups of national societal culture which will allow forming common to all citizens' national identity.

Key words: management of ethnocultural diversity, liberal integrating multiculturalism, theoretical model of public administration for ethnocultural diversity, principles of public administration of ethnocultural diversity.
\end{abstract}

Постановка проблеми. Проблеми в етнокультурній сфері, намагання деяких політиків та окремих держав-сусідів систематично нав'язувати тему етнічного протистояння в Україні свідчить про те, що впродовж тривалого часу, а саме - 3 моменту здобуття незалежності, в Україні не проводилася послідовна етнонаціональна політика, яка була б складовою внутрішньої і зовнішньої політики держави. Етнонаціональна політика повинна спрямовуватися на максимальне створення рівних можливостей для задо- волення потреб та інтересів усіх суб'єктів етнонаціональних відносин, а також на створення та приведення в дію важелів загальнонаціональної інтеграції і формування подвійної (етнічної та громадянської) ідентичності.

В Україні досі не прийнято концепції етнонаціонального розвитку, яка б визначала основні засади цієї політики, i це є зайвим доказом того, що питанням управління етнокультурною різноманітністю не приділялося належної уваги. Зокрема, не вдалося подолати наслідки 
всеохоплюючої русифікації та асиміляції українців в бік російської мови та культури, яка відбувалася в радянські часи. Вітчизняне законодавство 3 етнонаціональної політики, яке на перший погляд відповідає міжнародним стандартам, має низку прогалин. Нехтування проблемами етнонаціонального розвитку містить небезпеку перетворити фактор етнокультурної різноманітності 3 культурного надбання на джерело конфліктів та протиріч, призвести до втрати територіальної цілісності країни. Нерегульовані відносини між етнокультурними групами загострюють проблеми міжетнічного спілкування, збільшують потоки мігрантів, біженців, створюють конфліктні ситуації. Наслідком непослідовної етнонаціональної політики держави є наступні процеси та проблеми:

- Поглиблення етнорегіональних суперечностей, які перешкоджають становленню української політичної нації.

- Відсутність консенсусу щодо державної мови та статусу російської мови в Україні, зокрема введення регіональних мов на основі закону з великою кількістю спірних, необгрунтованих положень; наявність в Україні районів, де місцеве населення на знає і не розуміє української мови (деякі райони Закарпаття, Буковини, Донбасу, півдня України).

- Непрогнозованість процесів етнонаціонального розвитку через відсутність постійного їх моніторингу, виявлення проблем у цій сфері та налагодження етнокультурного діалогу.

- Необлаштованість депортованих народів, переселенців, новітніх іммігрантів.

- Пасивність окремих груп неетнічних українців у державотворчих процесах та процесах консолідації українського суспільства.

- Нерозв'язаність проблем зникаючих народів.

- Наявність соціально неадаптованих меншин, таких як роми, новітні іммігранти.

- Низький рівень, неефективна фахова підготовка державних службовців 3 етнонаціональних питань та відсутність координації дій органів державної влади і місцевого самоврядування.
Аналіз досліджень і публікацій. Питанням етнокультурної сфери присвячено праці багатьох українських та зарубіжних вчених. Зокрема, особливо корисними для цього дослідження були праці українських дослідників: О.Антонюка, В.Свтуха, А.Колодій, В.Котигоренка, I.Кураса, Ю.Куца, Ю.Левенця, Л.Лойко, О.Майбороди, О.Маруховської, Л.Нагорної, Г.Перепелиці, М.Рибачука, С.Римаренка, Ю.Римаренка, М.Степика, М.Товта; із зарубіжних - В.Кимлічки, Ч.Тейлора, Е.Сміта, Дж.Мейса, Т.Снайдера та ін. Однак, незважаючи на значну кількість наукових праць, присвячених цій сфері, проблематика вироблення теоретичних підходів до публічного управління етнокультурною різноманітністю в Україні ще не одержала належного системного і комплексного опрацювання та теоретичної розробки. Саме згадані обставини зумовили вибір теми та актуальність її дослідження.

Мета дослідження: визначити елементи концептуальної моделі публічного управління етнокультурною різноманітністю, сформулювати основні принципи управління, які їй відповідають, і запропонувати концептуальну (теоретичну) модель управління етнокультурною різноманітністю в Україні, основану на теорії інтегруючого ліберального мультикультуралізму.

Виклад основного матеріалу. Управління етнокультурною різноманітністю розглядається як органічна складова публічного врядування, що являє собою сукупність послідовних рішень і дій органів публічної влади та суб'єктів громадянського суспільства, спрямованих на задоволення відмінних соціальних, політичних та культурних потреб етнічних спільнот та окремих громадян, що належать до них, врегулювання проблем, що виникають між цими спільнотами, утвердження у суспільстві атмосфери міжетнічної толерантності, зміцнення загальнонаціональної єдності.

Результативність управління етнокультурною різноманітністю залежить від того, чи враховуються виклики, які постають у процесі етнонаціонального розвитку і чи відповідає воно принципам публічного управління; чи здатна вла- 
да гнучко реагувати на запити суб'єктів етнополітичних процесів; наскільки державна еліта зацікавлена у збереженні міжетнічної злагоди у суспільстві та гармонізації інтересів суб'єктів етнополітичних відносин. Сутність управління етнокультурною різноманітністю значною мірою залежить також від того, яку модель етнонаціонального розвитку обере держава.

Під моделлю, в даному контексті, ми розуміємо один з типових варіантів (зразків) управлінської діяльності у сфері міжетнічних стосунків, здійснення етнонаціональної політики.

Концептуальна модель - конкретний (типовий) спосіб якоїсь діяльності, що здійснюється на основі певної теоретичної концепції або емпірично сформованого підходу і систематично відтворюється. В основі такої моделі лежить формулювання мети, інституційних засобів її досягнення, які відповідають наявним умовам і не суперечать панівним суспільним цінностям та інтересам суспільних суб’єктів, задіяних у реалізації моделі.

В таблиці 1 , яку ми сформулювали у підсумку нашої роботи, елементами концептуальної моделі виступають: мета; умови; цінності; інтереси; інституційні засоби досягнення мети; теоретична концепція, що обгрунтовує узгодженість наявних компонентів; принципи. Принципами публічного врядування вважаємо ті провідні ідеї, які беруться за правило при здійсненні публічної політики у сфері міжетнічних відносин.

Метою управління етнокультурною різноманітністю є інтеграція та консолідація. Враховуючи особливості становлення і сучасного стану української етнічної нації, першою складовою сучасної моделі врядування у сфері міжетнічних відносин, на нашу думку, має бути забезпечення повноцінного функціонування титульної етнонації, розвитку її мови та культури, виконання нею ролі державотворчого народу, остаточного подолання проявів міноритарності i пов'язаних 3 цим психологічних комплексів. Заходи посиленої підтримки не прийнято застосовувати до національної більшості, однак вони були б дуже доречні у тих регіонах, де етнічні українці $€$ «меншиною в меншині». Другою складовою управління етнокультурною різноманітністю $€$ захист прав і сприяння розвитку культур національних меншин, а також створення нормальних умов для адаптації нових іммігрантів. Третя містка і дуже важлива складова управління етнокультурною різноманітністю - творення політичної (громадянської) нації через сприяння інтеграційним процесам, їх моделювання i втілення в життя через заходи етнонаціональної політики [2, с. 50].

Сьогодні наша країна проходить випробування щодо того, чи не зруйнують відмінності у свідомості окремих суспільних груп - етнічних, а ще більше регіональних - їхню здатність і їхне бажання разом творити і розвивати демократичну державу. Отже, питання культурної різноманітності та питання національної єдності й суспільної інтегрованості повинні розв'язуватися паралельно. Управління етнокультурною різноманітністю повинно базуватися на двох взаємно пов'язаних цілях: 1) створенні рівних можливостей для задоволення потреб та інтересів усіх суб'єктів етнонаціональних відносин; 2) забезпечення загальнонаціональної інтеграції і формування подвійної (етнічної та політичної) ідентичності.

Основу громадянської національної інтеграції і консолідації становлять не лише такі формальні ознаки як усвідомлення приналежності до однієї держави, громадянство, а й спільні інтереси та значна міра культурної єдності, яка виникає завдяки формуванню в полікультурному суспільстві значного шару поділюваної усіма культури, яка обслуговує суспільні інститути і яку називають соцієтальною. Вона формується навкруг певної етнокультурної серцевини (ядра), якою $\epsilon$ культура державотворчого етносу. Соцієтальна культура забезпечує консолідацію громадянської (політичної) нації, створюючи простір для достатньо інтенсивного спілкування етнокультурних груп, які можуть мати - на приватному рівні чи на рівні своєї етнічної громади - ще й інші вияви культурного життя. Саме це їі розуміння є корисним i має бути взяте до уваги при виробленні концептуальних засад етнонаціональної політики Української держави. У процесі 
розвитку соцієтального шару української національної культури відбуватиметься (також і насамперед) консолідація української етнонації як ядра і суб'єкта цього багаторівневого процесу [3, с.40-54].

Упродовж останніх років неодноразово науковці, політики, громадські діячі наголошували на необхідності прийняття Концепції етнонаціонального розвитку, котра б визначала основні засади публічного управління етнокультурною різноманітністю, сприяла б стабільному, демократичному розвитку держави. На нашу думку, в Україні управління етнокультурною різноманітністю повинно базуватися на адаптованій до українських реалій концепції інтегруючого мультикультуралізму, оскільки проблеми національної інтеграції та консолідації все ще є актуальними.

Перевага концепції інтегруючого мультикультуралізму полягає у повазі гідності всіх народів і рівному ставленні до їхні представників, державному захисті їхніх культурних прав, що забезпечуе етнокультурну справедливість. Управління етнокультурною різноманітністю, основане на мультикультуралізмі, передбачає сприяння процесам суспільної інтеграції, підтримку культурної різноманітності, захист індивідуальних прав представників етнокультурних груп, створення умов для збереження самобутності етнокультурних груп, розвиток загальнонаціональної соцієтальної культури, котра дозволить забезпечити формування спільної для всіх громадян національної ідентичності. Основне завдання - узгодити індивідуальні та групові права, збереження і розвиток етнічних культур паралельно з формуванням соцієтальної культури. Це передбачає можливість у разі потреби тимчасового використання засобів посиленої підтримки (позитивної дискримінації щодо тих груп, культура яких особливо пригнічувалася у попередній період).

Управління етнокультурною різноманітністю в Україні повинно бути скероване на «культури» етнокультурних груп з належною їх класифікацією і диференційованим підходом. Це сприятиме відновленню міжетнічної справедливості, збереженню етнокультурної різноманітності та консолідації українського суспільства. Концепція інтегруючого мультикультуралізму гарантуе дотримання індивідуальних прав людей та доповнюється колективними правами. Як принцип управління етнокультурною різноманітністю мультикультуралізм вимагає створення рівних можливостей для всіх етнокультурних груп зберігати, відтворювати свою культуру й ідентичність, а також передбачає піклування держави про гідність і добробут усіх її громадян. Примітно, що доктрина мультикультуралізму виходить за межі гарантування індивідуальних прав кожній особі. В ній йдеться також про визнання колективних прав етнічних та інших груп на захист своєї культури, оскільки це не суперечить загальнонаціональним цінностям і правам людини [1, с. 57]

Надання переваги моделі інтегруючого мультикультуралізму зумовлено також відмовою від моделі асиміляції, оскільки на сьогоднішній день є неприйнятним будь-який тиск сильніших культур на слабші, панівних на підпорядковані, державних на недержавні. Важливим аргументом також є зростання етнокультурної різноманітності суспільств та посилення етнічних рухів у багатьох країнах. Оскільки мультикультуралізм передбачає підтримку і збереження багатоманітності, він безперечно містить у собі потенційну загрозу розколу, роз'єднання етнонаціональних спільнот. Щоб уникнути цієї загрози, етнонаціональну політику, засновану на принципі мультикультуралізму, потрібно врівноважити іншими заходами, спрямованими на досягнення національної консолідації, такими як творення єдиного освітнього, інформаційного й культурного простору; запровадження патріотичного виховання i розвитку громадянського Руху; досягнення консенсусу в мовній сфері; знаходження і поширення на все суспільство соціальних та політичних цінностей, які були б визнані важливими та спільними для всієї нації і послужили основою для формування загальної української національної ідентичності, спільної для всіх громадян.

Принципи управління етнокультурною різноманітністю повинні виходити 
3 політики національної консолідації, спрямованої на усунення політичних i політико-культурних (ціннісних) розбіжностей - при повазі до етнокультурних відмінностей. Це - пріоритетне завдання усіх державних структур на тривалий час. В Україні відбувається процес консолідації нації довкола символів та цінностей, а не навколо етнокультурної традиції чи крові. Це - цінності, які лежать в основі сучасної боротьби України і мають широкий характер: свобода, гідність, незалежність, право вибору, віра в людину, а не в державу. Вони не є суто українськими - це ліберально-демократичні цінності. Однак саме вони можуть зміцнити і зробити тривалою ту єдність та консолідованість українського суспільства, які ми сьогодні спостерігаємо в умовах війни, як явище, що базується на спільному нещасті. Важливо, щоб українське суспільство змогло зберегти цю тимчасову єдність і тоді, коли це нещастя подолаємо.

3 метою запобігання перетворенню етнокультурних відмінностей на протистояння управління етнокультурною різноманітністю має базуватись на принципах ефективного врядування, визначених у Білій книзі Свропейського врядування: відкритість; участь; підзвітність; ефективність; узгодженість [7, с.11]. Вищезгадані принципи доповнили такі базові принципи $\mathrm{CC}$, як пропорційність та субсидіарність [5]. Це передбачає зростання децентралізаціі, зменшення ролі уряду, підвищення ролі інших суб'єктів етнонаціональної політики, дотримання субсидіарності, впровадження багаторівневого управління. Універсальність наведених принципів обумовлюється процесами формування єдиних підходів до створення якісного правового регулювання суспільних відносин з урахуванням особливостей політичної сфери їх застосування [6]. Враховуючи наявний в Україні досвід вирішення проблем етнонаціонального розвитку, принципи європейського врядування, концепція публічного управління етнокультурною різноманітністю має базуватись на наступних принципах:

1. Надійність, послідовність та ефективність публічного управління замість ситуативного, часто запізнілого ре- агування на проблеми у сфері міжетнічних стосунків. Вироблення і втілення в життя стратегії національної консолідації.

2. Відкритість та демократичність при формуванні законодавчої бази.

3. Загальна злагодженість публічного управління - рішення, що приймаються на локальному чи регіональному рівнях мають відповідати загальнодержавній концепції та її принципам.

4. Участь і взаємодія усіх зацікавлених сторін як суб'єктів врядування - 3 урахуванням особливостей громадської думки та специфічних рис менталітету у різних частинах країни, що сприятиме узгодженню позицій і виробленню загальноприйнятних рішень.

5. Формування єдиного культурного простору і спільної для всіх громадян соцієтальної культури - політика держави у сфері культури та мистецтва не може обмежуватися опікою деякими ділянками мистецького життя країни і фінансуванням окремих мистецьких проектів. Міністерство культури та інші органи виконавчої влади повинні сприяти формуванню відповідної інфраструктури, яка забезпечить формування та поширення цілісної, сучасної соцієтальної культури, яка обслуговує суспільні інститути [4, с.309-328].

Необхідна сукупність заходів публічної політики, щоб впровадити цю модель в життя. Прийняття та реалізація Концепції етнонаціонального розвитку створить передумови для послідовних та узгоджених дій держави, органів місцевого самоврядування та інститутів громадянського суспільства у цій сфері. Для координації дій з управління етнокультурною різноманітністю доцільно відновити діяльність окремого центрального органу виконавчої влади, що займатиметься цими питаннями. Також слід домагатися єдності культурного та інформаційного простору держави із запровадженням єдиної державної мови при вільному розвитку всіх інших мов поза офіційною сферою. Важливим заходом із зближення етнокультурних груп, що дозволить уникнути міжрегіонального напруження, є сприяння мобільності та змішуванню населення з різних регіонів, 
Табл.1

Структура теоретичної моделі публічного управління етнокультурною різноманітністю на основі концепції інтегруючого мультикультуралізму: компоненти та індикатори *.

\begin{tabular}{|c|c|c|}
\hline \multicolumn{2}{|l|}{ Компоненти } & \multirow{2}{*}{$\begin{array}{l}\text { Індикатори (ознаки присутності, риси) } \\
\text { - Відсутність міжетнічних і міжрегіональних } \\
\text { конфліктів; } \\
\text { - визнання загальнодержавних цінностей і по- } \\
\text { вага до них; } \\
\text { - національна єдність. }\end{array}$} \\
\hline Мета & $\begin{array}{l}\text { Національна консолідація, ін- } \\
\text { теграція етнокультурних груп } \\
\text { в українську політичну націю }\end{array}$ & \\
\hline Умови & $\begin{array}{l}\text { - Етнокультурна різнома- } \\
\text { нітність, наявність національ- } \\
\text { них меншин та етнічних груп; } \\
\text { - прояви міжетнічних і міжре- } \\
\text { гіональних суперечностей; } \\
\text { - несформована українська по- } \\
\text { літична нація; } \\
\text { - політична демократія пере- } \\
\text { буває в процесі становлення. }\end{array}$ & $\begin{array}{l}\text { - Етнокультурна гетерогенність доповнюєть- } \\
\text { ся спільним для усіх груп шаром соцієтальної } \\
\text { культури; } \\
\text { - провідним принципом міжетнічних стосунків } \\
\text { стає «єдність у різноманітності»; } \\
\text { - виникає і зміцнюється спільна для усіх груп } \\
\text { надетнічна українська національна ідентич- } \\
\text { ність; } \\
\text { - формується консенсус щодо демократичних } \\
\text { цінностей. }\end{array}$ \\
\hline Цінності & $\begin{array}{l}\text { - Демократичні цінності в дер- } \\
\text { жавному управлінні і суспіль- } \\
\text { них відносинах: свобода, рів- } \\
\text { ність, справедливість; } \\
\text { - етнокультурна справедли- } \\
\text { вість, відсутність } \\
\text { дискримінації; } \\
\text { - повага до особливостей куль- } \\
\text { тури усіх національностей, } \\
\text { їхьої особистої і групової гід- } \\
\text { ності. }\end{array}$ & $\begin{array}{l}\text { - Рівноправна залученість представників етно- } \\
\text { культурних груп до управління й самовряду- } \\
\text { вання; } \\
\text { - визнання на державному рівні національних } \\
\text { та релігійних свят; } \\
\text { - участь у формуванні органів держави, контролі } \\
\text { за їх діяльністю, підтриманні постійного кон- } \\
\text { такту з ними населення; } \\
\text { - толерантність і політична коректність у } \\
\text { міжетнічних стосунках. }\end{array}$ \\
\hline Інте & $\begin{array}{l}\text { - Збереження і розвиток етніч- } \\
\text { них культур, релігій та іден- } \\
\text { тичності; } \\
\text { - навчання рідною мовою; } \\
\text { - рівноправність та рівне став- } \\
\text { лення в судах і інших офіцій- } \\
\text { них установах; } \\
\text { - рівні можливості при здо- } \\
\text { бутті освіти та влаштуванні на } \\
\text { роботу; } \\
\text { - рівні можливості для полі- } \\
\text { тичної діяльності та участі у } \\
\text { прийнятті державних рішень; } \\
\text { - представництво в органах } \\
\text { місцевого самоврядування. }\end{array}$ & $\begin{array}{l}\text { - Наявність дорадчих органів при органах вико- } \\
\text { навчої влади; } \\
\text { - наявність шкіл з рідною для етнічних груп мо- } \\
\text { вою викладання ; } \\
\text { - наявність відповідної культурно-інформацій- } \\
\text { ної та релігійної інфраструктури; } \\
\text { - відсутність дискримінації при працевлашту- } \\
\text { ванні; } \\
\text { - рівність і справедливість як принцип функціо- } \\
\text { нування державних установ; } \\
\text { - представленість в органах місцевого самовря- } \\
\text { дування; } \\
\text { - наявність національно-культурних товариств } \\
\text { та інших громадських об'єднань етнічних груп. }\end{array}$ \\
\hline $\begin{array}{l}\text { Інституційні } \\
\text { засоби }\end{array}$ & $\begin{array}{l}\text { Нормативно-правове регулю- } \\
\text { вання, організаційне (на рівні } \\
\text { державних і громадських ін- } \\
\text { ституцій) і (частково) фінан- } \\
\text { сове забезпечення публічної } \\
\text { політики, спрямованої на } \\
\text { втілення в життя вищезазна- } \\
\text { чених цінностей та інтересів. }\end{array}$ & $\begin{array}{l}\text { - Наявність схваленої парламентом Концепції } \\
\text { етнонаціонального розвитку на засадах інтегру- } \\
\text { ючого мультикультуралізму та відповідних їй } \\
\text { законів; } \\
\text { - наявність відповідальних підрозділів у ЦодВ } \\
\text { (ВР, зокрема Комітет з прав людини і націо- } \\
\text { нальних меншин; в КМУ, Міністерстві культу- } \\
\text { ри, Держкомтелерадіо, Міносвіти); } \\
\text { - наявність відповідних підрозділів у обласних } \\
\text { та районних держадміністраціях і органах міс- } \\
\text { цевого самоврядування; }\end{array}$ \\
\hline
\end{tabular}




\begin{tabular}{|c|c|c|}
\hline & & $\begin{array}{l}\text { - фінансування етнічно-культурних організацій } \\
\text { або групових заходів та навчання рідною мовою; } \\
- \text { національно-культурні товариства та ї } \\
\text { об’єднання, інші громадські організації і до- } \\
\text { радчі структури за участю представників етно- } \\
\text { культурних груп. }\end{array}$ \\
\hline $\begin{array}{l}\text { Концеп- } \\
\text { туальні } \\
\text { засади }\end{array}$ & $\begin{array}{l}\text { - Підтримка української ет- } \\
\text { нонації, виконання нею ролі } \\
\text { державотворчого народу; } \\
\text { - захист прав і розвиток куль- } \\
\text { тур етнічних груп; } \\
\text { - творення політичної (грома- } \\
\text { дянської) нації через сприян- } \\
\text { ня інтеграційним процесам. }\end{array}$ & $\begin{array}{l}\text { - Повага до історії, національних традицій і сим- } \\
\text { волів, патріотизм; } \\
\text { - рівноправність громад як суб'єктів суспільно- } \\
\text { го життя й політики, наявність умов для їхнього } \\
\text { саморозвитку; } \\
\text { - панування державної мови в органах влади } \\
\text { та системі вищої (державної) освіти при повній } \\
\text { свободі використання мов етнічних груп у при- } \\
\text { ватному житті й житті їніх громад; } \\
\text { - культурні, освітні й наукові обміни, єдиний } \\
\text { інформаційно-культурний простір, взаємне зба- } \\
\text { гачення культур і спільне творення модерної } \\
\text { культури української політичної нації. }\end{array}$ \\
\hline Принципи & \multicolumn{2}{|c|}{$\begin{array}{l}\text { - Надійність, послідовність та ефективність публічного управління. } \\
\text { - Відкритість та демократичність при формуванні законодавчої бази. } \\
\text { - Загальна злагодженість публічного управління. } \\
\text { - Участь і взаємодія усіх зацікавлених сторін як суб’єктів врядування. } \\
\text { - Формування єдиного культурного простору і спільної для всіх громадян соціє- } \\
\text { тальної культури. }\end{array}$} \\
\hline
\end{tabular}

активізації їх культурного і виробничого спілкування. Держава повинна проводити заходи посиленої підтримки дискримінованих у минулому культур, у тому числі і української, для забезпечення рівного функціонування всіх культур. Повинна відбутися своєрідна модернізація культури - відмова від застарілих форм українськості та нав'язування їх іншим етносам.

При виробленні концептуальних підходів до управління етнокультурною різноманітністю вагома роль відводиться інститутам громадянського суспільства, дорадчим органам при органах виконавчої та законодавчої влади. Однак необхідно враховувати особливу роль держави. За державою необхідно закріпити законодавчу, координуючу та контролюючу функції.

Висновки. Отже, виходячи з вищеозначеного розуміння понять «концепту- альна модель» та «управління етнокультурною різноманітністю», ми пропонуємо модель публічного управління етнокультурною різноманітністю, засновану на демократичних цінностях (свободи, рівності, справедливості, у т.ч. й етнічної) та робочих (операційних) принципах (культурного плюралізму i визнання, деліберації і горизонтальної публічної координації, децентралізації й субсидіарності, національної інтеграції на основі соцієтальної культури, пріоритетності культурної та освітньої політики), що випливають $з$ двох теоретичних концепцій: демократичного врядування та інтегруючого мультикультуралізму.

Метою такого управління є національна консолідація та інтеграція етнокультурних груп в українську політичну націю. Засобом консолідації та міжетнічної інтеграції виступає соцієтальна культура.

\section{СПИСОК АIТЕРАТУРИ:}

1. Кимлічка В. Лібералізм і права меншин [Текст] / Віл Кимлічка. - Х. : Центр освітніх ініціатив «Демократична освіта», $2001-173$ с

2. Колодій А. Культурний плюралізм і етнонаціональна політика / А. Колодій // АГОРА. Випуск 4: Україна: подолання розбіжностей - розвиток особливостей. - К., 2007. - Вип. 
4. - C. $34-51$

3. Колодій А. Соцієтальна культура як чинник національної консолідації // Консолідація українського народу: конституційно-правові аспекти. Збірник статей за матеріалами науково-практичної конференції 28 лютого - 1 березня 2013 р. Львів, ЛНУ ім. Івана Франка. - Львів: Вид-во Львівського університету, 2013..

4. Колодій А. Міжрегіональні поділи в Україні та деякі принципи публічного врядування / Антоніна Колодій // Будуємо нову Україну: збірник конференції (26-27 листопада 2014 р., м. Київ). - Київ : Видавничий дім «Києво-Могилянська академія», 2015. - С. 309-328 - / [Електронний ресурс]. - Режим доступу до статті : http://www.ekmair.ukma.edu.ua/ handle/123456789/4607

5. Шевчук Б. Реформи управління в Європейському Союзі: основні напрямки, принципи, інструменти / Б.Шевчук / / Науковий вісник.- 2013.-Вип. 11 «Демократичне врядування». 6. Communication from the Commission to the European Parliament, the Council, the European Economic and Social Committee and the Committee of the Region. Smart Regulation in the European Union. - Брюсель, 8.10.2010 COM(2010) 543 final - [Електронний ресурс]. - Режим доступу: http://eur-lex.europa.eu/legal-content/EN/ALL/?uri=CELEX:52010DC0543

7. Governance in the European Union: A White Paper -Брюссель, 25.7.2001 COM(2001) 428 - C.11 [Електронний ресурс]. - Режим доступу: http:// ec.europa.eu/governance/index en.htmEuropean Governance : A White Paper. - Brussels, 2001, COM (2001) 428. - P. 11. Access mode : www.ec.europa.eu.

\section{REFERENCES:}

1. Kymlichka $V$. Liberalizm i prava menshyn (Liberalism and minority rights). - Kh. : Tsentr osvitnikh initsiatyv "Demokratychna osvita», $2001-173 \mathrm{p}$.

2. Kolodiy A. Kul'turnyy plyuralizm i etnonatsional'na polityka (Cultural pluralism and ethnic policy)// AHORA. Vypusk 4: Ukrayina: podolannya rozbizhnostey - rozvytok osoblyvostey. - K. 2007. - Vyp. 4. - P. 34-51

3. Kolodiy A. Sotsiyetal'na kul'tura yak chynnyk natsional'noyi konsolidatsiyi (Societal culture as a factor of national unity) // Konsolidatsiya ukrayins'koho narodu: konstytutsiyno-pravovi aspekty. Zbirnyk statey za materialamy naukovo-praktychnoyi konferentsiyi 28 lyutoho - 1 ber eznya 2013 r. L'viv, LNU im. Ivana Franka. - L'viv: Vyd-vo L'vivs'koho universytetu, 2013.

4. Kolodiy A. Mizhrehional'ni podily v Ukrayini ta deyaki pryntsypy publichnoho vryaduvannya (Inter-regional divisions in Ukraine and some principles of public governance) // Buduyemo novu Ukrayinu: zbirnyk konferentsiyi ( 26-27 lystopada 2014 r., m. Kyyiv). - Kyyiv : Vy davnychyy dim "Kyyevo-Mohylyans'ka akademiya», 2015. - S. 309-328 - /. - Access mode: http://www.ekmair.ukma.edu.ua/handle/123456789/4607

5. Shevchuk B. Reformy upravlinnya v Yevropeys'komu Soyuzi: osnovni napryamky, pryntsypy, instrumenty (Governance in the European Union: the basic directions, principles, tools)// Naukovyy visnyk.- 2013.-Vyp. 11 «Demokratychne vryaduvannya».

6. Communication from the Commission to the European Parliament, the Council, the European Economic and Social Committee and the Committee of the Region. Smart Regulation in the European Union. - Brussels, 8.10.2010 COM (2010) 543 final. - Access mode: http://eur-lex. europa.eu/legal-content/EN/ALL/?uri=CELEX:52010DC0543

7. Governance in the European Union: A White Paper -Брюссель, 25.7.2001 COM(2001) 428 P.11. - Access mode: http:// ec.europa.eu/governance/index_en.htmEuropean Governance : A White Paper. - Brussels, 2001, COM (2001) 428. - P. 11. - Access mode : www.ec.europa.eu.

Корнат Леся Ярославівна - аспірант

Львівський регіональний інститут державного управління Національної академії державного управління при Президентові України

Адреса: 79491, м.Львів-Брюховичі, вул. Сухомлинського, 16

E-mail: lesya_kornat@ukr.net

Kornat Lesya Yaroslavivna - postgraduate

Lviv regional institute of public administration, the National Academy of public administration, office of the President of Ukraine Address: 16, Sukhomlynsky Str., L`viv-Bryuxovy`chi, 79491, Ukraine

E-mail: lesya_kornat@ukr.net 